University of Nebraska - Lincoln

DigitalCommons@University of Nebraska - Lincoln

Faculty Publications: Department of

Entomology

Entomology, Department of

1993

\title{
Activity and Electrophoretic Characterization of Esterases in Insecticide-Resistant and Susceptible Strains of German Cockroach (Dictyoptera: Blattellidae)
}

\author{
Suresh K. Prabhakaran \\ University of Nebraska-Lincoln \\ Shripat T. Kamble \\ Universitiy of Nebraska--Lincoln, skamble1@unl.edu
}

Follow this and additional works at: https://digitalcommons.unl.edu/entomologyfacpub

Part of the Entomology Commons

Prabhakaran, Suresh K. and Kamble, Shripat T., "Activity and Electrophoretic Characterization of Esterases in Insecticide-Resistant and Susceptible Strains of German Cockroach (Dictyoptera: Blattellidae)" (1993).

Faculty Publications: Department of Entomology. 307.

https://digitalcommons.unl.edu/entomologyfacpub/307

This Article is brought to you for free and open access by the Entomology, Department of at DigitalCommons@University of Nebraska - Lincoln. It has been accepted for inclusion in Faculty Publications: Department of Entomology by an authorized administrator of DigitalCommons@University of Nebraska - Lincoln. 


\title{
Activity and Electrophoretic Characterization of Esterases in Insecticide-Resistant and Susceptible Strains of German Cockroach (Dictyoptera: Blattellidae)
}

\author{
SURESH K. PRABHAKARAN AND SHRIPAT T. KAMBLE \\ Department of Entomology \& Environmental Programs, University of Nebraska, \\ Lincoln, NE 68583-0816
}

\begin{abstract}
J. Econ. Entomol. 86(4): 1009-1013 (1993)
ABSTRACT Strains of German cockroach, Blattella germanica (L.), were tested for resistance to three insecticides using the time-mortality response technique in comparison with known susceptible strains. Dursban-R and Macy strains indicated high levels of resistance to chlorpyrifos and moderate resistance to propoxur and cypermethrin. The hydrolytic activity of esterase enzymes was determined with a model substrate, $p$-nitrophenyl acetate. The specific activity of the enzymes increased with a corresponding increase in substrate concentration. Maximum activity was observed at $80 \mu M$. The resistant strains had significantly higher activity than the susceptible strains. The enzyme activity also increased with an increase in $\mathrm{pH}$. Highest esterase activity was observed at $\mathrm{pH} 8.0$ for all the strains. The calculated Michaelis Menten constant $\left(\mathrm{K}_{\mathrm{m}}\right)$ values for the resistant strains were nearly two-fold higher than for the susceptible strains. Nondenaturing gel electrophoresis revealed differences in isozyme composition. In total, 10 esterase bands were detected, and these bands were characterized using different inhibitors and substrates.
\end{abstract}

KEY WORDS Blattella germanica, resistance, esterase

THE GERMAN COCKROACH, Blattella germanica (L.), is one of the most important pests of households and commercial food processing establishments. It is also of medical importance because of its ability to mechanically transmit organisms which cause human diseases (Frishman \& Alcamo 1977). These cockroaches also contaminate food, dishes, and other articles in homes, food stores, restaurants, and hospitals. Home-dwellers and commercial pest control operators use substantial quantities of insecticides to control German cockroach populations. Repeated insecticide applications have led to the development of resistance by this insect. The literature revealed several publications on German cockroaches resistant to organochlorine, organophosphate (OP), carbamate, and pyrethroid insecticides (Grayson 1966, Scott \& Matsumura 1981, Schal 1988, Cochran 1989, Rust \& Reierson 1991, Zhai \& Robinson 1992).

Insecticide resistance in insects has been correlated with elevated esterase production and activity. Resistance mechanisms for OP and carbamate insecticides in German cockroaches have been reported to involve the combined effects of increased oxidative and hydrolytic enzymes (Siegfried et al. 1990, Siegfried \& Scott 1991). However, hydrolytic enzymes from German cockroaches have not been fully characterized.
Therefore, our research involved the measurement of insecticide resistance and the determination of esterase activity with a model substrate under various $\mathrm{pH}$ conditions. Additional characterization was done based on the electrophoretic mobilities and staining of different isozymes.

\section{Materials and Methods}

Cockroach Strains. Two susceptible strains, Jwax (S. C. Johnson and Son, Racine, WI) and CSMA (Cornell University, obtained through B. Siegfried, University of Nebraska, Lincoln) were used for comparison. Field strain (Macy) cockroaches were collected from several units managed by the Omaha Tribal Housing Authority, Macy, NE. The Dursban-R cockroach strain, resistant to several OP insecticides, was provided by B. Siegfried, University of Nebraska, Lincoln. All cockroaches were reared at $27 \pm 2^{\circ} \mathrm{C}, 60 \pm$ $10 \% \mathrm{RH}$, and a photoperiod of 12:12 (L:D) h. The cockroach colonies were reared on Purina dog chow (Ralston Purina, St. Louis, MO) and water and maintained in Plexiglas containers ( 30 by 30 by $30 \mathrm{~cm}$ ).

Chemicals. The technical grade insecticides and their concentrations used in the study were: chlorpyrifos ( $99 \%$, DowElanco, Indianapolis, IN), $4.0 \mu \mathrm{g} / \mu \mathrm{l}$ of acetone; propoxur $(99.41 \%$, En- 
Table 1. Toxicity of insecticides to different strains of German cockroach

\begin{tabular}{|c|c|c|c|c|c|c|c|c|c|c|c|c|}
\hline \multirow{2}{*}{ Strain } & \multicolumn{4}{|c|}{ Chlorpyrifos } & \multicolumn{4}{|c|}{ Propoxur } & \multicolumn{4}{|c|}{ Cypermethrin } \\
\hline & $n$ & Slope \pm SE & $\mathrm{LT}_{50}{ }^{a}$ & $95 \% \mathrm{CI}$ & $n$ & Slope $\pm S E$ & $\mathrm{LT}_{50}{ }^{a}$ & $95 \% \mathrm{CI}$ & $n$ & Slope $\pm S E$ & $\mathrm{LT}_{50}{ }^{a}$ & $95 \% \mathrm{CI}$ \\
\hline & 6 & & 78 & 85.2 & 6 & 4 & 1 & 99.3 & 61 & & 9 & 8 \\
\hline & 6 & & 96. & & 6 & & & & 60 & & & \\
\hline ban-R & 60 & 0.5 & 670 & $609.8-751.2$ & 60 & 1.9 & 415.3 & 356.4 & 60 & $=0.2$ & 262.9 & $221.6-327.1$ \\
\hline Macy & 60 & $5.9 \pm 0.7$ & 468.8 & $434.9-504.6$ & 60 & $1.7 \pm 0.2$ & 268.2 & $231.9-315.7$ & 60 & $2.1 \pm 0.2$ & 502.6 & $428.2-622.1$ \\
\hline
\end{tabular}

${ }^{a} \mathrm{LT}_{50}$ expressed in minutes.

vironmental Protection Agency, Research Triangle Park, NC), $3.0 \mu \mathrm{g} / \mu \mathrm{l}$ of acetone; and cypermethrin $(86.2 \%$, ICI Americas, Richmond, CA), $0.8 \mu \mathrm{g} / \mu \mathrm{l}$ of acetone. Eserine, paraoxon $(90 \%)$, $p$-nitro phenyl acetate, and electrophoresis reagents were obtained from Sigma Chemical, St. Louis, MO.

Bioassay Method. Bioassays were done by topical application of $0.5 \mu \mathrm{l}$ of acetone-diluted insecticide to the ventral side of the first abdominal segment. All insecticides were applied with a programmable micro syringe (Microlab P; Hamilton Bonaduz Ag, Switzerland). Each insecticide treatment included 10 male cockroaches from each strain; treatments were replicated six times. Treated cockroaches were transferred to clean petri plates containing food and water. Timemortality responses were initially recorded at intervals of 5-10 min and at longer intervals as the experiment progressed. Data were pooled and analyzed by probit analysis (SAS Institute 1985). $\mathrm{LT}_{50} \mathrm{~s}$ were estimated for each strain against each insecticide. The test of statistical significance between the appropriate $\mathrm{LT}_{50} \mathrm{~s}$ was failure of their $95 \%$ fiducial limits to overlap. In addition, a resistance ratio (RR) was calculated according to the formula $R R=L T_{50} \mathrm{R}$ strain divided by $L_{50} S$ strain, where $R$ is the test strain and $S$ is the CSMA strain.

Preparation of Enzymes. For electrophoresis and enzyme assay, 10 adult German cockroaches were homogenized in a Teflon glass homogenizer in $3 \mathrm{ml}$ of $0.1 \mathrm{M}$ sodium phosphate buffer ( $\mathrm{pH} 7.0$ ) containing $0.5 \%$ Triton $\mathrm{X} \cdot 100$. The homogenate was centrifuged for $20 \mathrm{~min}$ at $25^{\circ} \mathrm{C}$ at $10,000 \times \mathrm{g}$, and the supernatant was filtered through a $45-\mu$ disposable filter assembly (Gelman Sciences, Ann Arbor, MI) and used as the enzyme source.

Protein and Esterase Determination. The protein concentration was determined by the method of Bradford (1976). Total esterase activity was measured using the procedure described by Townson (1972). Each sample was added to $5 \mathrm{ml}$ reaction mixture containing $20-80 \mu M \quad p$ nitrophenyl acetate (PNPA), $0.08 \%$ methanol, and $0.1 M$ phosphate buffer. $\mathrm{A}_{400}$ was monitored at different $\mathrm{pH}$ values ranging from 6.0 to 9.0 . The reaction rates were calculated over the initial 10 min against a series of standard solutions of $p$-nitrophenol $(10-60 \mu M)$ and corrected for spontaneous hydrolysis of PNPA. The difference in specific activity among strains was analyzed using Fisher's least significant difference (LSD), $P>0.05$ (SAS Institute 1985).

Electrophoresis. Nondenaturing polyacrylamide gel electrophoresis (PAGE) was performed in a Bio-Rad vertical electrophoresis unit (Richmond, CA) using $8.0 \%$ polyacrylamide gel and tris-glycine buffer. Each sample (3 $\mu \mathrm{g}$ of protein) was loaded along with $10 \%$ sucrose and diluted 1:1 with running buffer. Electrophoresis was conducted at a constant $200 \mathrm{~V}$. The gels were stained for esterase activity in $100 \mathrm{ml}$ of $0.2 \mathrm{M}$ phosphate buffer (pH 6.5) containing $2 \% \alpha$ naphthyl acetate and $0.04 \mathrm{~g}$ fast blue BB salt at $25^{\circ} \mathrm{C}$ for $1 \mathrm{~h}$. The gels were then transferred to $7 \%$ acetic acid for storage.

Esterase Characterization. The cholinesterase and carboxylesterase bands in the polyacrylamide gels were identified by incubating them with the inhibitors eserine and paraoxon (Sivakumaran \& Mayo 1991). The alkaline and acid phosphatases were identified with sodium-2naphthyl phosphate and sodium-l-naphthyl phosphate using the procedure of Loxdale et al. (1983). Esterase characterization was replicated at least six times.

\section{Results and Discussion}

Bioassay. The susceptible strain Jwax had a higher $\mathrm{LT}_{50}$ value than the CSMA strain for all the insecticides tested (Table 1), but the response was not significant at the $\mathrm{LT}_{95}$ level. The

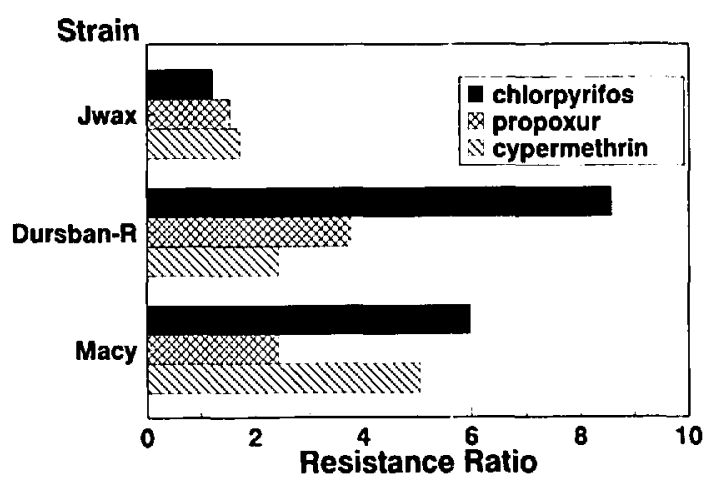

Fig. 1. Levels of resistance to three insecticides in different strains of German cockroach. 
Table 2. Esterase activity in German cockroach strains at various substrate levels at pH $\mathbf{7 . 0}$

\begin{tabular}{lccccr}
\hline \hline \multirow{2}{*}{ Strain } & \multicolumn{4}{c}{ Specific activity at PNPA ${ }^{a}$ concentration $(\mu$ moles/min/mg of protein) } \\
\cline { 2 - 6 } & 20 & 40 & 50 & 60 & 80 \\
\hline Jwax & $4.814 \pm 0.156 \mathrm{a}$ & $6.036 \pm 0.306 \mathrm{a}$ & $7.157 \pm 0.176 \mathrm{ab}$ & $8.380 \pm 0.176 \mathrm{ab}$ & $9.093 \pm 0.306 \mathrm{a}$ \\
CSMA & $4.281 \pm 0.796 \mathrm{a}$ & $5.285 \pm 1.413 \mathrm{a}$ & $6.166 \pm 0.337 \mathrm{a}$ & $6.981 \pm 0.730 \mathrm{a}$ & $7.942 \pm 0.864 \mathrm{~b}$ \\
Dursban-R & $4.839 \pm 0.969 \mathrm{a}$ & $6.872 \pm 0.256 \mathrm{a}$ & $7.967 \pm 0.248 \mathrm{~b}$ & $9.632 \pm 0.240 \mathrm{~b}$ & $11.220 \pm 0.361 \mathrm{c}$ \\
Macy & $4.785 \pm 0.214 \mathrm{a}$ & $7.589 \pm 1.892 \mathrm{a}$ & $8.621 \pm 0.566 \mathrm{~b}$ & $9.921 \pm 0.439 \mathrm{~b}$ & $11.621 \pm 0.783 \mathrm{c}$ \\
\hline
\end{tabular}

Mean \pm SEM of three separate preparations with three determinations each. Means within the same column followed by the same letter are not significantly different (LSD, $P>0.05$ ).

a $p$-nitrophenyl acetate.

two resistant strains, Dursban-R and Macy, indicated a high level of resistance to chlorpyrifos and a moderate resistance level to propoxur (Fig. 1). Siegfried et al. (1990) reported similar findings for Dursban- $\mathrm{R}$ strain based on $\mathrm{LD}_{50}$ values. There was a 5-fold resistance in Macy strain to cypermethrin. This strain had been exposed to chlorpyrifos and cypermethrin by pest control operators for at least 2 yrs before collection for this research. Similar development of resistance to pyrethroids because of repeated applications was reported in German cockroaches (Atkinson et al. 1991).

Enzyme Activity. Data on spectrophotometric analysis of esterases indicated a higher enzyme activity in the resistant strains compared with the susceptible strains (Table 2). Similarly enhanced esterase activity toward naphtholic esters in two resistant strains of German cockroaches was reported by Siegfried \& Scott (1992). The specific activity of the esterases from different strains was similar at lower substrate concentrations but significantly different at higher PNPA concentrations. All four cockroach strains had the highest esterase activity at $80 \mu M$ PNPA. The strain Jwax exhibited a comparable specific activity with the resistant strains at all PNPA concentrations except at $80 \mu M$ PNPA.

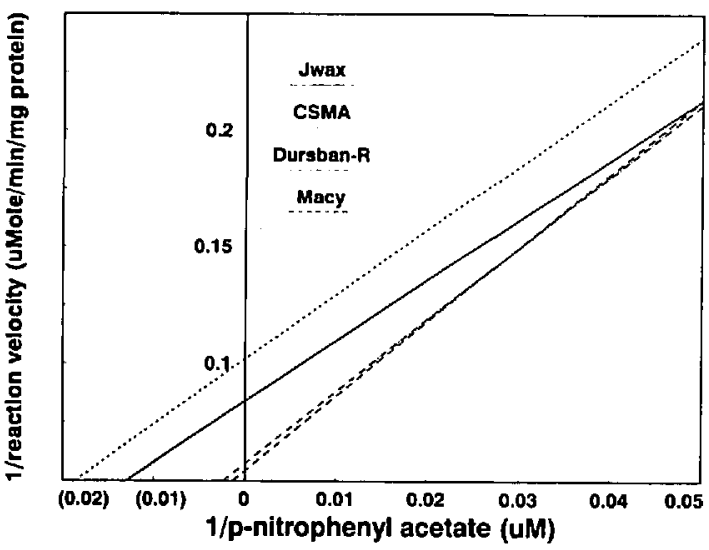

Fig. 2. Lineweaver-Burk plot of kinetics of esterases from four strains of German cockroach determined using different concentrations of $p$-nitrophenyl acetate.
The Michaelis constant $\left(\mathrm{K}_{\mathrm{m}}\right)$ estimated by the Lineweaver-Burk plot (Fig. 2) with PNPA as a substrate at $\mathrm{pH} 7.0$ revealed an $\approx 2$-fold increase in $\mathrm{K}_{\mathrm{m}}$ value for the resistant strains compared with the susceptible strains (Table 3). A similar difference was observed for the maximum reaction rate $\left(V_{\text {max }}\right)$ between the strains. The $K_{n 1}$ values for Dursban-R and Macy strains were significantly different at the $5 \%$ level when compared with CSMA and Jwax strains. A 2-fold difference in $K_{m}$ values of esterase isozymes between strains was reported for Aedes aegypti (L.) (Townson 1972). Although it has not been clearly established that the same form of enzyme that catalyzes insecticide metabolism is involved in hydrolysis of the model substrate, a 2-fold difference in $K_{m}$ and $V_{\max }$ between susceptible and resistant strains indicates either a modification in the efficiency of the enzyme or increased production of the enzyme.

Effect of $\mathbf{p H}$. There was a considerable increase in esterase activity from $\mathrm{pH} 6.0$ to 9.0 with a maximum activity at $\mathrm{pH} 8.0$ in all strains. No significant differences were observed between the mean specific activities of the esterases from resistant and susceptible strains at $\mathrm{pH} 6.0$ and 6.5 , but significant differences were observed from $\mathrm{pH} 7.0$ to 9.0 (Table 4). A general decline in total esterase activity was noted at $\mathrm{pH} 9.0$ compared with activity at $\mathrm{pH} 8.0$.

Gel Electrophoresis. Nondenaturing PAGE of the homogenates from each strain stained for $\alpha$-naphthyl acetate indicated differences in composition of esterase isozymes. Esterase bands were designated as E1-E10 (Fig. 3a), indicating $\mathrm{E} 1$ as the slowest migrating esterase and E10 as the fastest. E1 and E2 were two separate bands

Table 3. Michaelis-Menten constant $\left(K_{m}\right)$ values for esterases from German cockroach strains

\begin{tabular}{lc}
\hline Strain & $\mathrm{K}_{\mathrm{m}} \times 10^{-4} M^{\mathrm{a}}$ \\
\hline CSMA & $0.267 \mathrm{a}$ \\
Jwax & $0.303 \mathrm{a}$ \\
Dursban-R & $0.523 \mathrm{~b}$ \\
Macy & $0.570 \mathrm{~b}$ \\
\hline
\end{tabular}

${ }^{a}$ Means within a column followed by the same letter are not significantly different (LSD, $P>0.05$ ). Substrate: $p$-nitrophenyl acetate, $\mathrm{pH}$ 7.0. 
Table 4. Effect of $\mathrm{pH}$ on the activity of esterases from German cockroach strains

\begin{tabular}{lccccc}
\hline \hline \multirow{2}{*}{ Strain } & \multicolumn{5}{c}{ Specific activity at different pH ( $\mu$ moles/min/mg of protein) } \\
\cline { 2 - 6 } & 6.0 & 6.5 & 7.0 & 8.0 & 9.0 \\
\hline Jwax & $3.286 \pm 0.306 \mathrm{a}$ & $3.516 \pm 0.214 \mathrm{a}$ & $9.093 \pm 0.306 \mathrm{a}$ & $12.047 \pm 0.176 \mathrm{a}$ & $10.621 \pm 0.529 \mathrm{a}$ \\
CSMA & $3.075 \pm 0.558 \mathrm{a}$ & $4.136 \pm 0.356 \mathrm{a}$ & $7.942 \pm 0.864 \mathrm{a}$ & $11.887 \pm 1.934 \mathrm{a}$ & $10.709 \pm 0.425 \mathrm{a}$ \\
Dursban-R & $3.947 \pm 0.672 \mathrm{a}$ & $6.234 \pm 0.242 \mathrm{~b}$ & $11.220 \pm 0.361 \mathrm{~b}$ & $16.152 \pm 0.388 \mathrm{~b}$ & $14.600 \pm 0.194 \mathrm{~b}$ \\
Macy & $4.080 \pm 0.167 \mathrm{a}$ & $4.828 \pm 0.241 \mathrm{a}$ & $11.621 \pm 0.783 \mathrm{~b}$ & $16.904 \pm 0.333 \mathrm{~b}$ & $14.682 \pm 0.192 \mathrm{~b}$ \\
\hline
\end{tabular}

Mean \pm SEM of three separate preparations with three determinations each. Means within the same column followed by the same letter are not significantly different (LSD, $P>0.05$ ).

in the Macy strain but the other strains exhibited only a strongly stained E2 band. Similarly, E8, $\mathrm{E} 9$, and E10 bands stained strongly in Macy strain compared with other strains. E9 and E10 bands stained weakly in Dursban-R strain. The differences in staining intensities may be related

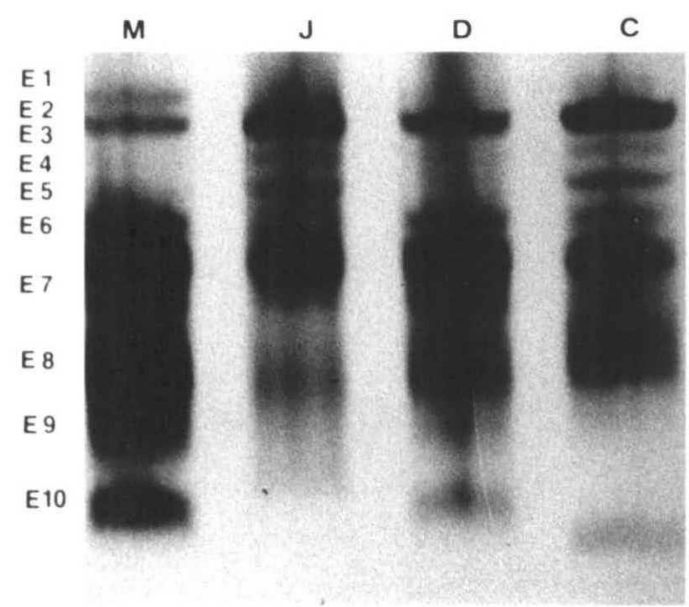

a.

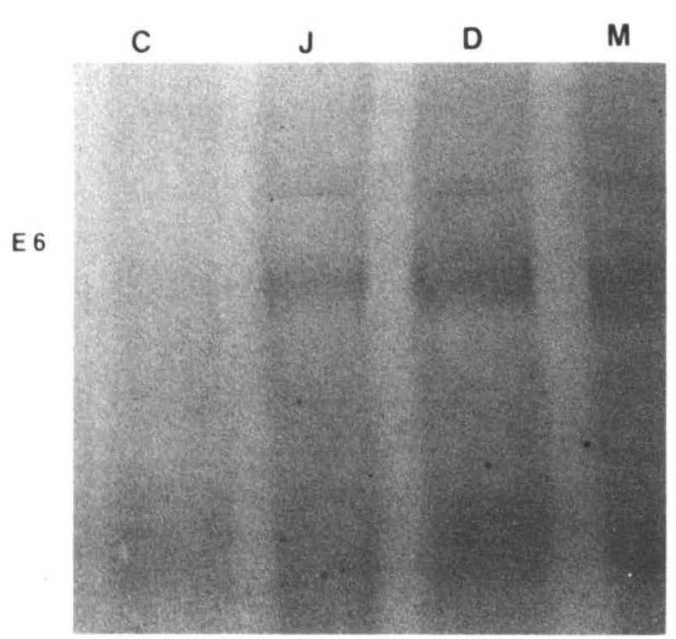

c.

Fig. 3. Esterase isozymes on polyacrylamide gel electrophoresis (a) Incubation in $\alpha$-naphthyl acetate and fast blue BB salt. (b) Incubation in eserine $\left(10^{-5}\right)$ before $\alpha$-naphthyl acetate and fast blue salt addition. (c) Incubation in sodium acetate ( $\mathrm{pH}$ 5.0) containing sodium-1-naphthyl acid phosphate and fast blue salt. (d) Incubation in sodium borate $(\mathrm{pH} 9.0)$ containing sodium-2-naphthyl phosphate and fast blue salt. The letters $\mathrm{M}, \mathrm{D}, \mathrm{J}$, and $\mathrm{C}$ designate Macy, Dursban-R, Jwax, and CSMA, respectively. to individual isozyme activity to the substrate used or the genetic variations among strains.

When polyacrylamide gels were incubated in a cholinesterase inhibitor, eserine $\left(10^{-5} \mathrm{M}\right)$, before the addition of $\alpha$-naphthyl acetate and fast blue salt, bands E1, E2, E3, E4, and E5 exhib-
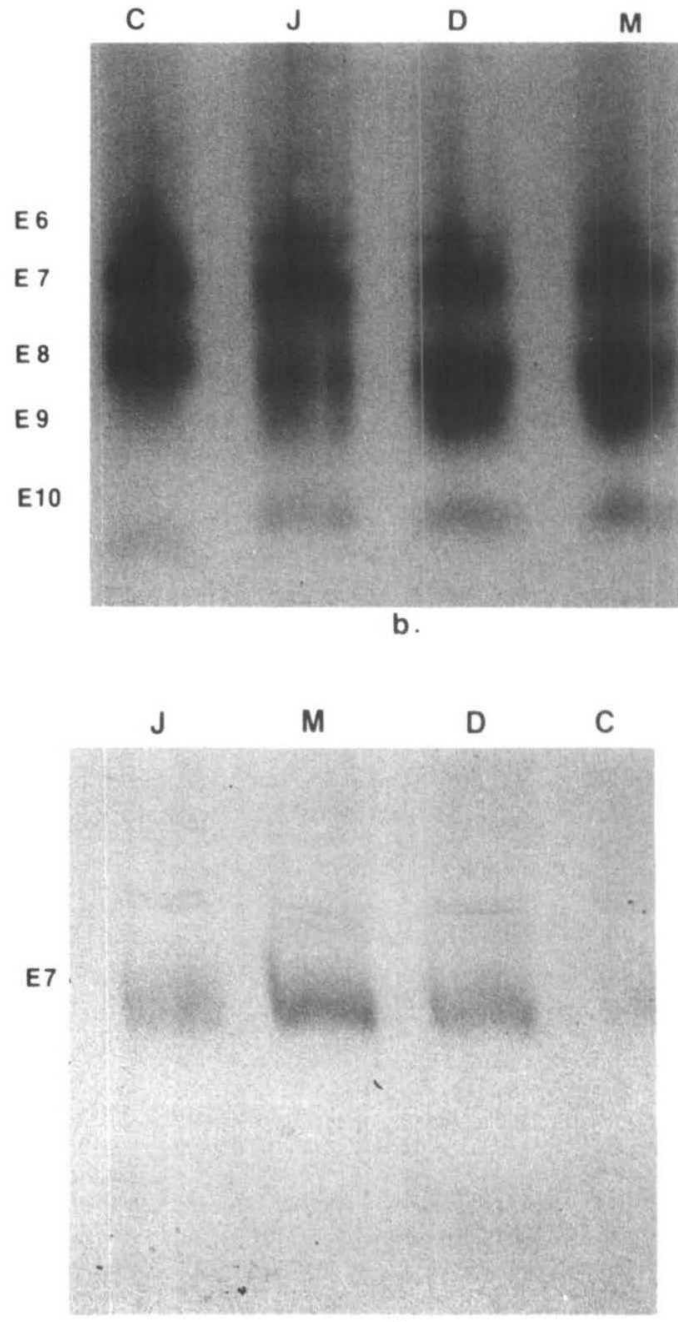

d. 
ited reduced staining (Fig. $3 \mathrm{~b}$ ), indicating that these bands belong to cholinesterase type of enzymes. However, the E10 band of the Macy strain displayed only weak staining, indicating the presence of a cholinesterase type of isozyme with an electrophoretic mobility similar to E10. The staining intensity of the other bands was found to be similar. When the gels were incubated in paraoxon $\left(10^{-6} M\right.$ ) (an OP compound that inhibits both cholinesterases and carboxylesterases) before the addition of $\alpha$-naphthyl acetate and fast blue salt, all the bands except E6 and E7 disappeared. However, these two bands stained very weakly. Based on these results, the bands E8, E9, and E10 were classified as carboxylesterases. Similar chemicals and concentrations were used to identify the cholinesterases and carboxylesterases in green peach aphid, Myzus persicae (Sulzer) (Beranek 1974) and greenbug, Schizaphis graminum (Rondani) (Sivakumaran \& Mayo 1991). The band E6 was characterized as acid phosphatase by incubating the gel in $50 \mathrm{mM}$ sodium acetate (pH 5.0) containing sodium-1-naphthyl acid phosphate and fast blue for $1 \mathrm{~h}$ (Fig. 3c). The alkaline phosphatase band E7 was identified by incubating the gel in $60 \mathrm{mM}$ sodium borate ( $\mathrm{pH} 9.0$ ) containing sodium-2-naphthyl phosphate and fast blue salt (Fig. 3d). The intensity of staining was generally very weak for the phosphatases, especially in the susceptible strains.

These results provide baseline information for further research on the involvement of esterases in the resistance mechanism of German cockroaches.

\section{Acknowledgments}

The authors thank Blair Siegfried and John Foster (University of Nebraska, Lincoln) for their critical review of this manuscript. This is published as Paper 10066, Journal series, Nebraska Agricultural Research Division, and Contribution 807, Department of Entomology, University of Nebraska, Lincoln.

\section{References Cited}

Atkinson, T. H., R. W. Wadleigh, P. G. Koehler \& R. S. Patterson. 1991. Pyrethroid resistance and synergism in a field strain of the German cockroach. J. Econ. Entomol. 84: 1247-1250.

Beranek, A. P. 1974. Esterase variation and organophosphate resistance in populations of Aphis fabae and Myzus persicae. Entomol. Exp. Appl. 17: 129141.

Bradford, M. M. 1976. A rapid and sensitive method for the quantitation of microgram quantities of pro- tein utilizing the principle of protein dye binding. Anal. Biochem. 72: 248-254.

Cochran, D. G. 1989. Monitoring for resistance in field-collected strains of the German cockroach. J. Econ. Entomol. 82: 336-341.

Frishman, A. M. \& I. E. Alcamo. 1977. Domestic cockroaches and human bacterial disease. Pest Control 45: 16-46.

Grayson, J. M. 1966. Recent developments in the control of some arthropods of public health and veterinary importance: cockroaches. Bull. Entomol. Soc. Am. 12: 333-338.

Loxdale, H. D., P. Castanera \& C. P. Brookes. 1983. Electrophoretic study of enzymes from cereal aphid populations. I. Electrophoretic techniques and staining systems for characterizing isoenzymes from six species of cereal aphids (Hemiptera: Aphididae). Bull. Entomol. Res. 73: 645-657.

Rust, M. K. \& D. A. Reierson. 1991. Chlorpyrifos resistance in German cockroaches from restaurants. J. Econ. Entomol. 84: 736-740.

SAS Institute. 1985. SAS user's guide: statistics. SAS Institute, Cary, NC.

Schal, C. 1988. Relation among efficacy of insecticides, resistance levels, and sanitation in the control of the German cockroach. J. Econ. Entomol. 81: 536-544.

Scott, J. G. \& F. Matsumura. 1981. Characteristics of a DDT-induced case of cross resistance to permethrin in Blattella germanica. Pestic. Biochem. Physiol. 16: 21-27.

Siegfried, B. D. \& J. G. Scott. 1991. Mechanisms responsible for propoxur resistance in the German cockroach. Pestic. Sci. 33: 133-146.

1992. Biochemical characterization of hydrolytic and oxidative enzymes associated with chlorpyrifos and propoxur resistance in the German cockroach, Blattelia germanica (L.). J. Econ. Entomol. 85: 1092-1098.

Siegfried, B. D., J. G. Scott, R. T. Housh \& B. C. Zeichner. 1990. Biochemistry and genetics of chlorpyrifos resistance in the German cockroach, Blattella germanica L. Pestic. Biochem. Physiol. 38: $110-121$.

Sivakumaran, S. \& Z B Mayo. 1991. Electrophoretic characterization of esterases in the greenbug, Schizaphis graminum. J. Kans. Entomol. Soc. 64: 357-362.

Townson, H. 1972. Esterase polymorphism in Aedes aegypti: the genetics and $\mathrm{K}_{\mathrm{m}}$ values of electrophoretically heterogenous forms. Ann. Trop. Med. Parasitol. 66: 255-266.

Zhai, J. \& W. H. Robinson. 1992. Measuring cypermethrin resistance in the German cockroach. J. Econ. Entomol. 85: 348-351.

Received for publication 17 August 1992; accepted I February 1993. 